\title{
ANALYZING THE STRATEGIC ALIGNMENT BETWEEN INFORMATION SYSTEM TECHNOLOGY AND BUSINESS PROCESS IN SMALL MEDIUM ENTERPRISE (SME) USING FRAMEWORK COBIT 4.1- A CASE STUDY IN UNIVERSAL TRADING, SURABAYA
}

\author{
Benih Hartanti \\ STIE PGRI Dewantara \\ e-mail: benih_ak@stiedewantara.ac.id
}

\begin{abstract}
ABSTRAK
This research was conducted in Universal Trading as one of SME that applies Information Technology as daily business process in order to analyze whether the use of Information Technology is alligned with the strategy formulation. Type of research is Descriptive Research with Qualitative technique by using direct observation and depth interview with all user of TI from leader to staff. In depicting a further detail description, Internal and External Matrixas well as COBIT Verse 4.1 were utilized in supporting so. From the position of Average as a result of IFE-EFE Matrix and the Score of COBIT 4.1 in primary process of Strategic Allingment is 2,95 could be concluded that only strategy of new market penetration could be alligned by the use of Information Technology as the company basic business process is limiting the strategy of new product development using only company's internal source.
\end{abstract}

Keyword: strategic allignment, information technology, COBIT 4.1

\section{INTRODUCTION}

Developing countries, Indonesia particularly, has been in concern of investing mark by many developed countries, as well as the developing countries. On economic justification for the last few years that Indonesia has been able to prove on its capability to survive in 2008 and 2012 global crisis. In the 2012, Indonesia hadn't been too affected(Raz, 2012)by the impact of the crisis. It was even predicted that Indonesia able to survive in Crisis 2012 with 6,5\% of growth (Djohan, 2011). In comparison with other countries, Indonesia had performed its valuable index in global competitiveness pre and within the crisis. According to Global Competitiveness Report (Scwhab \& Brende, 2012) Indonesia had positioned the rank of 50 in overall global index from all 144 countries included.

Accordingly, the domestic economy has been supporting the condition. SME as one of the Indonesia's survival factor is able to deliver the contribution on the stability, or the growth during the crisis. Refer to (Rahman, 2006) and followed by (Khusnir, et al., 2010) present that SMEs in Indonesia been acknowledged on increasing number, showing the number as 99\% part of firms in Indonesia, around the rural and urban area. However, SMEs in Indonesia haven't been maximizing all the expected potential activities in increasingly globalized and international trade (Tambunan, 2011). Aside from the bureaucracy in Indonesia that has been the obstacle to conduct so, one of these factors are leading to another as one stated by one of the observer SME and one of the SME's player in Indonesia in his book that most SME's in Indonesia are indicated as the on their lack capacity in adapting new environment in global era. 
In the lack of maximizing the SMEs activities in Indonesia, there are several factors causing the occurrence. Also reported by (Tambunan, 2011)several reasons affecting the lack, (1) the lack of technology (2) the lack of skilled workers (3) minimal knowledge about market potential and global business strategies and (4) minimum access to capital to finance. On contrary today's facts, technology is one the "Must Property" in nowadays business activities. Sourcing, manufacturing, communicating, negotiating, dealing is experienced at ease by utilizing technology. Hence, its lack of application as on one of the factors affecting the un-maximized business activities, have been also studied and presented on emerging countries (Vatanasakdakul, Tibben, \& Cooper, 2004). As an comparison, or could be considered as a brace studies, even SMEs in China (Chong, Shafaghi, \& Tan, 2011), UK (Houghton \& Winklhofer, 2004) and Australia (Parker \& Castleman, 2009) which are identified as the developed countries have been also showing the same result on the technology application.

The rapid development of global business forces SMEs to change the daily business process into more productive practice, especially for SMEs that run the business in Export Import Industry. Accurate and just in time information are required to support the immediate decision making. Thus, the application of information technology is more than just a communication tool, it is required to be set up as the tools to support the company in achieving strategic goals. Definite input, process and output need to be determined deliberately in order to supporting the company's strategy. The urgent need of Information System which combines people, organization and technology need to be noticed further by the SMEs Company that could contribute in specific system in order to align with company's strategy. While in opposing the ideal purpose, it is reported by International Data Communication described by (Fakhrana, 2016) shows that SMEs in Indonesia only use Information Technology for experimentation, means its use only for basic function which is data silo with no determined risk, while the main purpose should be for managing and optimizing tools to deliver the competitive advantage.

Furthermore, this research purpose is describing the alignment between strategy formulation and utilization of information technology. By employing COBIT 4.1 framework as a tool to depict the maturity of information technology utilization in supporting strategy formulation, this research is intended to generatea better awareness and understanding to the owner and or manager in SMEs to maximize the employment of Technology Information in further expanding employment.

\section{LITERATURE REVIEW}

\section{Strategic Management and Strategy Formulation}

According to (David, 2011), Strategic management can be defined as the art and science of formulating, implementing, and evaluating cross-functional decisions that enable an organization to achieve its objectives. Depicted from the definition, the most essential concern on strategic management is the cross-functional to gather the information in supporting the decision making and the steps in conducting so by implementing:

a. Strategy formulation: developing vision and mission, identifying the external and internal factors, determining the long term objectives, as well as determining the alternative strategy and select the strategy to implement as target. 
b. Strategy implementation: develop annual objective, designing the policy, allocating the resource to execute the strategy.

c. Strategy evaluation: to review whether the strategy selection and implementation is reaching the expected result.

Yet again, it is emphasizing that strategic formulation requires the interaction among the functions. Even though most of the organization structure in SMEs not dividing the Information Technology as an independent division or department, the use by each user need to determined. As any other department, information technology need to aim its defined objectives. Thus, it is very crucial that in each phase of information technology cycle need to be aligned with the objectives of company's strategic as a whole.

\section{Framework COBIT 4.1 as a Measurement Tools for Information Technology Performance}

For many enterprises, information and the technology that supports it represent their most valuable, but often least understood, assets. Successful enterprises recognize the benefits of information technology and use it to drive their stakeholders' value. The need for assurance about the value of IT, the management of IT-related risks and increased requirements for control over information are now understood as key elements of enterprise governance. Value, risk and control constitute the core of IT governance.

Control Objectives for Information and related Technology (COBIT $\left.{ }^{\circledR}\right)$ developed by IT Governance Institute (ITGI) provides good practices across a domain and process framework and presents activities in a manageable and logical structure. COBIT's good practices represent the consensus of experts. They are strongly focused more on control, less on execution. These practices will help optimize IT-enabled investments, ensure service delivery and provide a measure against which to judge when things do go wrong.

For IT to be successful in delivering against business requirements, management should put an internal control system or framework in place. The COBIT control framework contributes to these needs by:

1. Making a link to the business requirements

2. Organizing IT activities into a generally accepted process model

3. Identifying the major IT resources to be leveraged

4. Defining the management control objectives to be considered

The business orientation of COBIT consists of linking business goals to IT goals, providing metrics and maturity models to measure their achievement, and identifying the associated responsibilities of business and IT process owners.

The IT resources identified in COBIT can be defined as follows:

1. Applications are the automated user systems and manual procedures that process the information.

2. Information is the data, in all their forms, input, processed and output by the information systems in whatever form is used by the business.

3. Infrastructure is the technology and facilities (i.e., hardware, operating systems, database management systems, networking, multimedia, and the environment that houses and supports them) that enable the processing of the applications. 
4. People are the personnel required to plan, organize, acquire, implement, deliver, support, monitor and evaluate the information systems and services. They may be internal, outsourced or contracted as required

To govern IT effectively, it is important to appreciate the activities and risks within IT that need to be managed. They are usually ordered into the responsibility domains of plan, build, run and monitor. Within the COBIT framework, these domains are called(IT Governance Institute, 2007):

1. Plan and Organize (PO) - Provides direction to solution delivery (AI) and service delivery (DS)

2. Acquire and Implement (AI) - Provides the solutions and passes them to be turned into services

3. Deliver and Support (DS) - Receives the solutions and makes them usable for end users

4. Monitor and Evaluate (ME)-Monitors all processes to ensure that the direction provided is followed

\section{Strategic Alignment between Business's Goal and Information Technology}

Whilst information technology is providing such information by the criterion

built in the business requirement, defining a set of business objective and IT objectives which only provides the business related is one of the great challenge to any company, in SMEs, the challenge is indeed more compelling. As previously stated, business strategic management need to be determined clearly as it is including the process of formulation, implementation and evaluation among the department in the company.

In many cases of SMEs, the simplest thing to conduct the process is by determining their internal and external factor that strengthen and weakened the business in order to win the competition. General accepted tools is by using Internal Factor Evaluation (IFE) and External Factor Evaluation (EFE) matrix. Also referred to (David, 2011)EFE and IFE matrix method is a strategic-management tool often used for assessment of current business conditions.Even though, the tools are quite simplistic, they do the best job possible in identifying and evaluating the key affecting factors. The EFE and IFE matrix is indeed a good tool to visualize and prioritize the opportunities and threats that a business is facing.

The EFE and IFE matrix process utilizing five steps by (Jurevicius, 2014) :

1. Listing factors: The first step is to gather a list of external factors. Divide factors into two groups: opportunities and threats.

2. Assigning weights: Assign a weight to each factor. The value of each weight should be between 0 and 1 (or alternatively between 10 and 100 if you use the 10 to 100 scale). Zero means the factor is not important. One or hundred means that the factor is the most influential and critical one. The total value of all weights together should equal 1 or 100 .

3. Rating factors: Assign a rating to each factor. Rating should be between 1 and 4 . Rating indicates how effective the firm's current strategies respond to the factor. $1=$ the response is poor. $2=$ the response is below average. 3 above average. $4=$ superior. Weights are industry-specific. Ratings are company-specific.

4. Multiplying weights by ratings: Multiply each factor weight with its rating. This will calculate the weighted score for each factor.

5. Calculating total all weighted scores: Add all weighted scores for each factor. This will calculate the total weighted score for the company. 
Furthermore, the use of Information technology in business process could be only concluded as success whether it leverages the business as a whole system. There is indeed no defined predicament regarding the success factors of the success of IT implementation. However, many research have determined result that could be used as the reference whether or not IT implementation is indeed generating a value added for the company.

According to several scholars summarized in (Gondodiyoto, 2007) stated that in order to be succeed in implementing IT in business, terms need to concerned as below:

1. The interaction of technology and the organization - a broad concept that lays the groundwork for many of the other factors for consideration.

2. User involvement and participation - influenced by a number of variables that must be carefully balanced in order to ensure success of the involvement.

3. Resistance - can work for or against a project depending upon how it is managed.

4. Commitment - an essential ingredient for success but, because it involves a plethora of forces including the human psyche, is a challenge to achieve and maintain.

5. Planning - more able to be controlled by project managers than other success factors, and involving many critical components.

6. Risks - exist with every project but must be anticipated and managed in order to achieve success.

Thus, in mediating the business goal and IT implementation, COBIT is generally employed by many companies as it assists companies with its focus area as below:

1. Strategic alignment focuses on ensuring the linkage of business and IT plans; defining, maintaining and validating the IT value proposition; and aligning IT operations with enterprise operations.

2. Value delivery is about executing the value proposition throughout the delivery cycle, ensuring that IT delivers the promised benefits against the strategy, concentrating on optimizing costs and proving the intrinsic value of IT.

3. Resource management is about the optimal investment in, and the proper management of, critical IT resources: applications, information, infrastructure and people. Key issues relate to the optimization of knowledge and infrastructure.

4. Risk management requires risk awareness by senior corporate officers, a clear understanding of the enterprise's appetite for risk, understanding of compliance requirements, transparency about the significant risks to the enterprise and embedding of risk management responsibilities into the organization.

5. Performance measurement tracks and monitors strategy implementation, project completion, resource usage, process performance and service delivery, using, for example, balanced scorecards that translate strategy into action to achieve goals measurable beyond conventional accounting.

Each of the focus has divided the domain of COBIT in order to generate a guidance for company in evaluating the IT as depicted in below (IT Governance Istitute, 2007): 


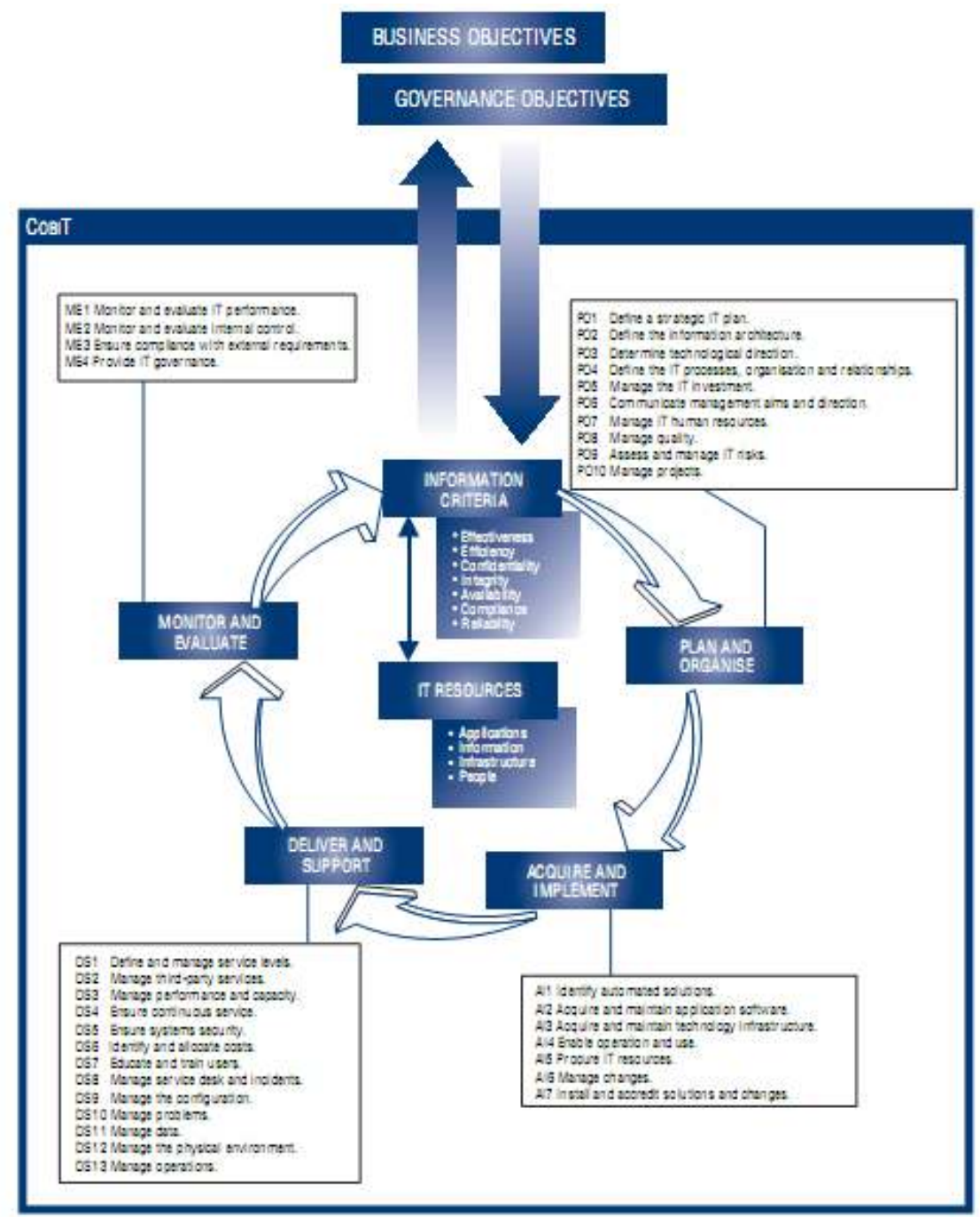

Figure 1. COBIT 4.1 Domain

However, since the research only focus on Strategic Alignment, thus only several items in each domain used (Sarno, 2009):

Table 1. COBIT Control Objective on Strategic Alignment

\begin{tabular}{cll}
\hline Focus Area & \multicolumn{1}{c}{ Control Objectives } \\
\hline & PO1 & Define a Strategic IT Plan \\
\cline { 2 - 3 } & PO2 & Define the Information Architecture \\
\cline { 2 - 3 } & PO6 & Communicate Management Aims and Direction \\
\cline { 2 - 3 } SO7 & Manage IT Human Resources \\
\cline { 2 - 3 } Strategic & PO8 & Manage Quality \\
\cline { 2 - 3 } & PO9 & Assess and Manage IT Risks \\
\cline { 2 - 3 } & PO10 & Manage Projects \\
\hline & AI1 & Identify Automated Solutions \\
\cline { 2 - 3 } & DI2 & Acquire and Maintain Application Software \\
\cline { 2 - 3 } & ME1 & Define and Manage Service Levels \\
\cline { 2 - 3 } & ME4 & Provide IT Governance \\
\hline
\end{tabular}




\section{RESEARCH METHODOLOGY}

\section{Research framework}

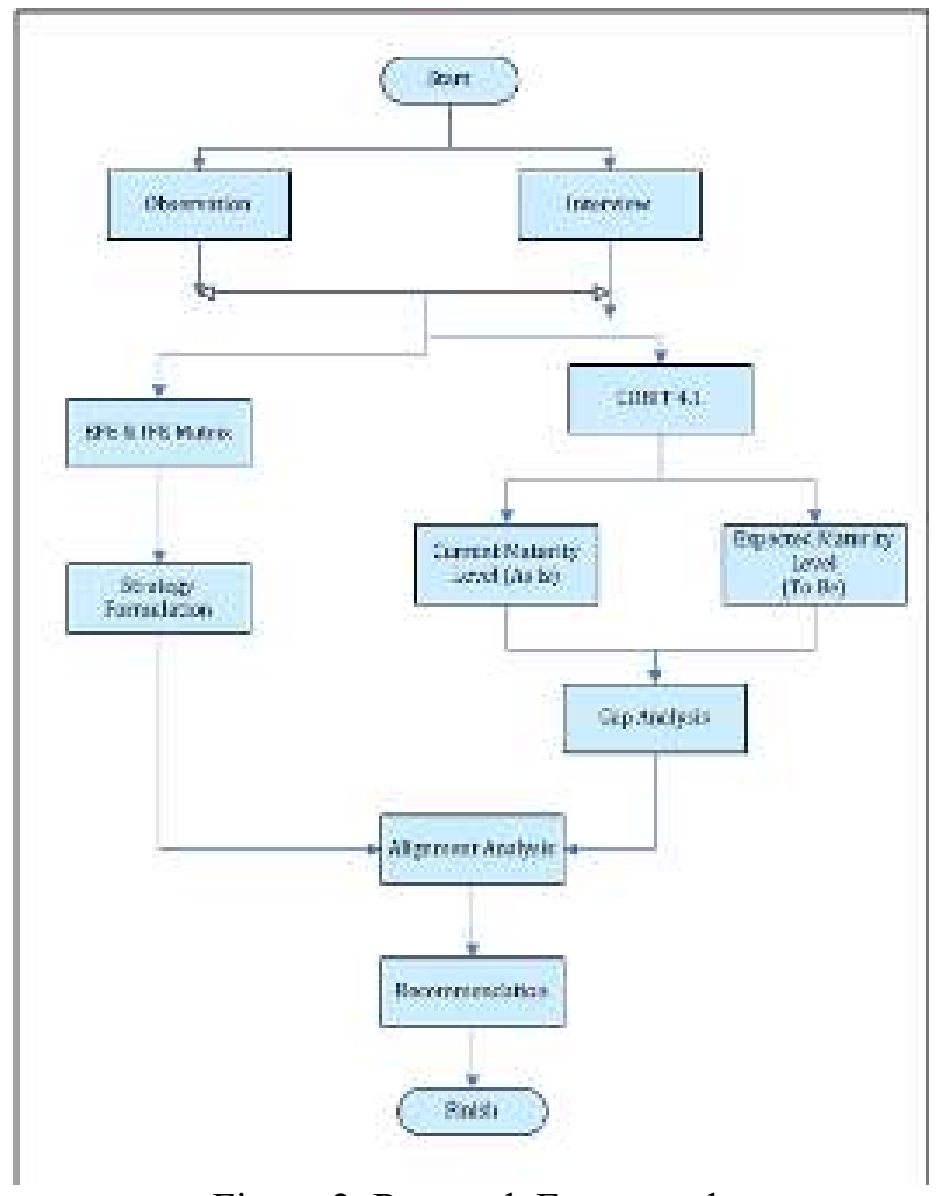

Figure 2. Research Framework

According to (Cooper \& Schindler, 2008) qualitative method is used in research as it includes an array of interpretive techniques which seek to describe, decode, translate and otherwise come to terms with the meaning, not the frequency. Furthermore, (Ritchie \& Lewis, 2003) also stated that qualitative research is able in generating a broad and comprehensive functions, one of which is evaluative, appraising the effectiveness of what exists. Analytic tools is required in order to help researcher aims the purpose of the research. Also according to (Ritchie \& Lewis, 2003), analytic hierarchy is different in every qualitative method, second stage is descriptive account which includes identifying elements and dimensions, refining categories, classifying data as well as sorting data by theme or concept (in cross-sectionalanalysis). Thus, based on the research framework, this research is employing qualitative method with descriptive analysis through observation and depth interview.

\section{Sample of Research}

Sample of the research is key personnel in each department of Universal Trading. The identification of respondent is defined referred to (IT Governance Istitute, 2007) as Responsible, accountable, consulted and or Informed (RACI) which representing the key stakeholder of the company. However, due to the company scale and limitation of 
human resource, several respondents have multiple function in RACI. Below are the key stakeholders involved:

Table 2. Key Stakeholder in Universal Trading

\begin{tabular}{lllc}
\hline No & $\begin{array}{c}\text { Key Stakeholder in } \\
\text { COBIT }\end{array}$ & \multicolumn{1}{c}{$\begin{array}{c}\text { Department in Universal } \\
\text { Trading }\end{array}$} & $\begin{array}{c}\text { Number of } \\
\text { Personnel }\end{array}$ \\
\hline 1 & Chief Executive Officer & Director & 1 \\
\hline 2 & $\begin{array}{l}\text { Chief Information } \\
\text { Officer }\end{array}$ & $\begin{array}{l}\text { Management Representative/ } \\
\text { Finance Manager }\end{array}$ & 1 \\
\hline 3 & $\begin{array}{l}\text { Business Process } \\
\text { Owner }\end{array}$ & Director & 1 \\
\hline 4 & Head Operations & $\begin{array}{l}\text { Import, International Sales \& } \\
\text { Export Manager }\end{array}$ & 3 \\
\hline 5 & Chief Architect & $\begin{array}{l}\text { External Assigned } \\
\text { Programmer }\end{array}$ & 1 \\
\hline 6 & $\begin{array}{l}\text { Compliance, Audit, } \\
\text { Risk and Security }\end{array}$ & External Assigned Consultant & 1 \\
\hline 7 & Service Manager & $\begin{array}{l}\text { Import, International Sales \& } \\
\text { Export Manager }\end{array}$ & 3 \\
\hline
\end{tabular}

\section{Data Processing}

Subsequently by collecting data through observation and interview, data processing in this research is including several stage :

1. Data checking - it is performed in order to generate assurance regarding the sufficient of data collected

2. Tabulation - it is performed in order to depict the data collected by using Microsoft excel and word. This stage is used both to calculate the response for IFE and EFE Matrix also for Maturity Level in COBIT.

\section{RESULT AND DISCUSSION}

Universal Trading is one of the trading company in Surabaya. The company is international food trading company to cater industry and retail with comprehensive product range. The industry is at Export Import with main business process is trading, by which it generates service to customers in acquiring the best product with competitive price through the supplier network. Built in 2004, Universal Trading has been managing the business process into five departments, which is Import, International Sales, Export, Human Resource and Finance.

In managing the strategic formulation, implementation and evaluation, management review have been conducted in weekly, monthly, quarterly and yearly meeting. The main strategy formulation is conducted as yearly meeting to gather the insight in evaluating previous term strategy implementation and formulating new strategy for the next term. In formulating the strategy, each department is assigned to present the internal and external factors as the content in formulating the strategy. Mainly using the Internal and External Factor Analysis in order to gather a comprehensive SWOT Analysis.

Since its establishment, electronic data processing already being implemented to support the daily business process. Though, the implementation is only limited in basic Microsoft Office, such as Excel, however, the dependency is considered high due to 
highly rate of various data required by stakeholders. Moreover, as the industry is emerging, as well as the number of both suppliers and customers, the requirement of data processing has been indeed imposing the company to employ more sophisticated program in supporting so. Thus, by January 2015, a customized program has been implemented to support each department in organizing daily business process.

The program is developed by using Embarcadero Delphi which is a programming language and software development kit (SDK) for desktop, mobile, web, and console applications by which the function is as component library for cross-platform native app development with flexible Cloud services and broad IoT connectivity. Since the implementation, each personnel in each department has their own proportion and authority in the program application and being applied into user management of the program.

Regarding the strategy, what will be described further is the Internal and External Factors with Weight according to Management Review.

Table 3. Internal Factor Analysis (IFE)

\begin{tabular}{|c|c|c|c|}
\hline STRENGTHS & Weight & Rate & $\begin{array}{l}\text { Weight } x \\
\text { Rate }\end{array}$ \\
\hline 1 Defined Company Vision \& Mission & 0.08 & 3.38 & 0.27 \\
\hline $\begin{array}{l}\text { Good cooperation and communication inter } \\
\text { department }\end{array}$ & 0.07 & 3.5 & 0.25 \\
\hline $\begin{array}{l}\text { Computerized Management Information } \\
\text { System }\end{array}$ & 0.07 & 3 & 0.21 \\
\hline $4 \quad$ Developed Accounting and Finance System & 0.07 & 2.5 & 0.18 \\
\hline $\begin{array}{ll}5 & \text { Excellent Human Resource }\end{array}$ & 0.07 & 2.75 & 0.19 \\
\hline $6 \quad$ Good Relationship with customers & 0.08 & 3 & 0.24 \\
\hline $7 \quad$ Good Relationship with suppliers & 0.08 & 3.13 & 0.25 \\
\hline $\begin{array}{ll}\text { Good Reward and Appreciation System for } \\
\text { Employee }\end{array}$ & 0.07 & 3.13 & 0.22 \\
\hline Total Weight Strengths & 0.59 & & 1.80 \\
\hline WEAKNESSES & Weight & Rate & $\begin{array}{l}\text { Weight } x \\
\text { Rate }\end{array}$ \\
\hline 9 Unable to provide certain customers' demand & 0.07 & 1.75 & 0.12 \\
\hline 10 Undeveloped market segmentation & 0.07 & 1.75 & 0.12 \\
\hline $\begin{array}{l}11 \text { Limited source to product development } \\
\text { Product development }\end{array}$ & 0.07 & 1.5 & 0.11 \\
\hline 12 Less Employee Training Program & 0.06 & 2 & 0.12 \\
\hline 13 Risk in Uncollectible Receivables & 0.07 & 2 & 0.14 \\
\hline 14 Defined Organization Culture & 0.07 & 2.13 & 0.15 \\
\hline Total Weight Weaknesses & 0.41 & & 0.76 \\
\hline Grand Total & 1 & & 2.56 \\
\hline
\end{tabular}


Table 4. External Factor Analysis

\begin{tabular}{llllc}
\hline \multicolumn{1}{c}{ OPPORTUNITIES } & Weight & Rate & Weight x Rate \\
\hline 1 & Geographically Potential & 0.1 & 3.38 & 0.34 \\
\hline 2 & Market is still growing & 0.11 & 3 & 0.33 \\
\hline 3 & Wide Product Variant for various industry & 0.11 & 2.88 & 0.32 \\
\hline 4 & Market share & 0.1 & 2.5 & 0.25 \\
\hline 5 & Technology development in industry & 0.09 & 2.13 & 0.19 \\
\hline Total Weight Opportunities & 0.51 & & 1.43 \\
\hline \multicolumn{1}{c}{ THREAT } & Weight & Rate & Weight x Rate \\
\hline 9 & Government Policy for fish product & 0.1 & 2 & 0.20 \\
\hline 10 & Global Economy & 0.1 & 1.88 & 0.19 \\
\hline 11 & Natural factors & 0.09 & 1.5 & 0.14 \\
\hline 12 & $\begin{array}{l}\text { Risk in direct transaction between supplier } \\
\text { and customer }\end{array}$ & 0.1 & 2 & 0.20 \\
\hline 13 & Less margin & 0.1 & 2.25 & 0.23 \\
\hline Total Weight Threat & 0.49 & & 0.95 \\
\hline Grand Total & 1 & & 2.37 \\
\hline
\end{tabular}

Based on the tabulation, the position of company in the coordinate of Internal and External Matrix is $(\mathrm{X}, \mathrm{Y}):(2.56: 2,37)$ which is in the position of Average. In this position the fit strategy is to Hold and maintain and the growing strategy need to implement is Market Penetration and Product Development. Therefore, in this position, Universal Trading is still in highly development industry filled with potential opportunities than threat. Universal Trading is also still able to maximize the internal factors, especially computerized management information system and defined accounting and finance system in order to be more competitive in the industry. The coordinate of Universal Trading position in Internal and External Matrix is depicted as below:

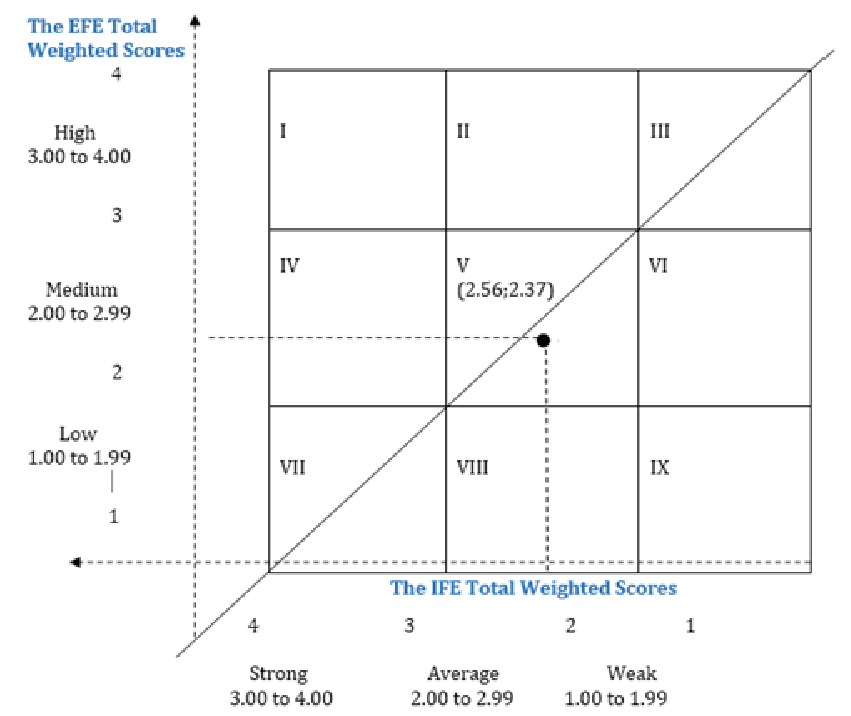

Figure 3. Internal \& External Factor Matrix

Furthermore, regarding the implementation of information technology, the tabulation of COBIT in domain related of Strategic Alignment is presented in below table : 
Table 5. Gap Analysis of Strategic Alignment in

\begin{tabular}{lllccc}
\hline Focus Area & \multicolumn{2}{l}{ Control Objectives } & As - Is & To - be & Gap \\
\hline $\begin{array}{l}\text { Strategic } \\
\text { Alignment }\end{array}$ & PO1 & Define a Strategic IT Plan & 3.7 & 4 & 0.3 \\
\cline { 2 - 6 } & PO2 & $\begin{array}{l}\text { Define the Information } \\
\text { Architecture }\end{array}$ & 2.9 & 4 & 1.1 \\
& PO6 & $\begin{array}{l}\text { Communicate Management Aims } \\
\text { and Direction }\end{array}$ & 3.7 & 4 & 0.3 \\
& PO7 & Manage IT Human Resources & 3.5 & 4 & 0.5 \\
\cline { 2 - 6 } & PO8 & Manage Quality & 3 & 4 & 1 \\
\cline { 2 - 6 } & PO9 & Assess and Manage IT Risks & 1.8 & 4 & 2.2 \\
\cline { 2 - 6 } & PO10 & Manage Projects & 1.8 & 4 & 2.2 \\
\cline { 2 - 6 } & AI1 & Identify Automated Solutions & 2.8 & 4 & 1.2 \\
\cline { 2 - 6 } & AI2 & $\begin{array}{l}\text { Acquire and Maintain Application } \\
\text { Software }\end{array}$ & 3.7 & 4 & 0.3 \\
& DS1 & Define and Manage Service Levels & 3.5 & 4 & 0.5 \\
\cline { 2 - 6 } & ME3 & $\begin{array}{l}\text { Ensure Compliance with External } \\
\text { Requirements }\end{array}$ & 2.7 & 4 & 1.3 \\
& ME4 & Provide IT Governance & 2.3 & 4 & 1.7 \\
\hline Average & & 2.95 & 4 & 1.05 \\
\hline
\end{tabular}

Moreover, the position of overall process maturity in order to fulfill the focus area of Goal Setting and Measurement, the position of Universal Trading could be depicted in below:

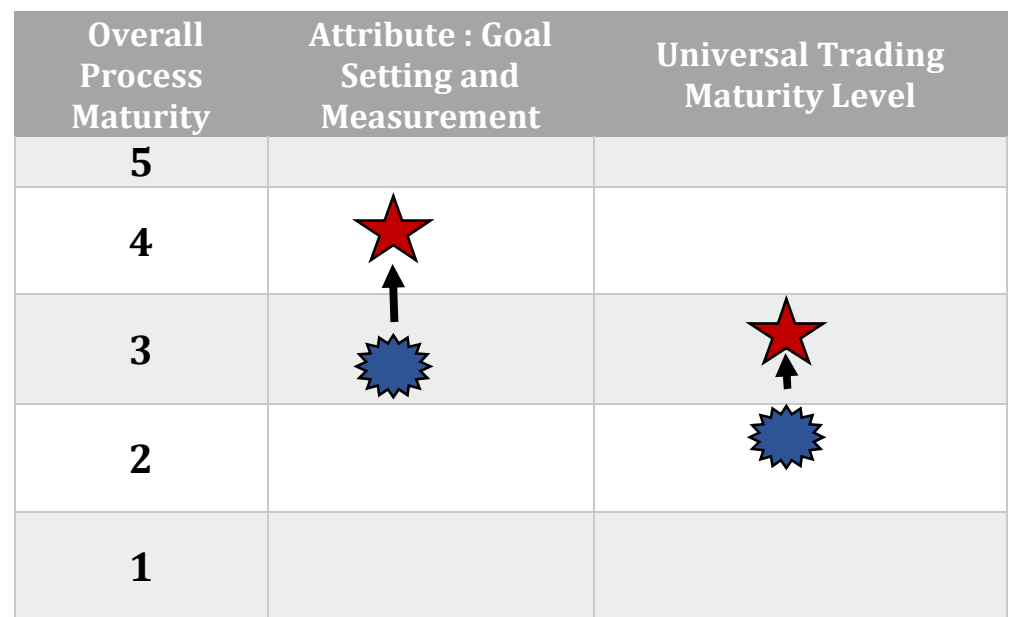

Figure 4. Position of Universal Trading

Thus, in resolving the gap as well as to support goal setting and measurement, recommendation for assessing enhanced information technology are as follow:

1. Procedures need to be standardized and documented, and most importantly communicated through training that involving all the personnel and or user including the leader/manager. It is mandated that these processes should be followed, though the procedures themselves are not sophisticated but are the formalization of existing practices.

2. Management should monitors and measures compliance with procedures and takes action where processes appear not to be working effectively. Processes are under 
constant improvement and provide good practice. Automation and tools need to be used even in a limited or fragmented way.

However, due to current company business process in the industry included, only Market Penetration that most likely is applicable for the information technology to support. Yet, the possibility for product development is still widely opened in the future strategy formulation following the possibility of company development that including the enhancement and even the alteration of business process.

Precisely, to designate the substantial assessment in recommendation, Universal Trading need to elaborate more detail procedure in market expansion by Marketing Executive and Marketing Coordinator with also involving a periodical sequence documented data storage of each user. Prominently, the requirement of procedural monitor and measurement is elevated, thus the involvement of leader is indeed very critical.

\section{CONCLUSIONS}

As the aim of the study is to elaborate the company's strategy and the maturity level of Information Technology as well as to analyze whether these two categorization is aligned, it could be concluded that certain business process using information technology need to conduct deliberately. As the result of the observation in the implementation of information technology as well as the interview with the key stakeholders, in order to reach the strategic alignment, the use of information technology need to reach the level 3-4 while current position is in 2-3, though the value is indeed approaching level 3 described in point 2,9. In this point, strategy that could be only supported by information technology is market penetration by maximizing the database information system yet with the support of all users including the leader/manager in monitoring and controlling the daily business process.

\section{REFERENCES}

Cooper, D. R. \& Schindler, P. S., 2008. Business Research Method. 10 ed. New York: McGraw-Hill.

David, F. R., 2011. Strategic Management : Concept \& Cases. 13th ed. New Jersey: Prentice Hall.

Djohan, M., 2011. Indonesia's Economy to Survive Global Economic Crisis. [Online] Available at: http://news.xinhuanet.com/english/business/2011-12/15/c/ $\underline{131309048 . h t m}$

Fakhrana, R. S., 2016. Riset: UKM Indonesia Belum Sadar Teknologi. [Online] Available at: http://www.cnnindonesia.com/teknologi/20160728154426-185147674/riset-ukm-indonesia-belum-sadar-teknologi/ [Accessed 1 April 2017].

Gondodiyoto, S., 2007. Audit Sistem Informasi - Pendekatan COBIT. 1st ed. Jakarta: Mitra Wacana Media.

IT Governance Istitute, 2007. COBIT 4.1 Excerpt. [Online] Available at: https://www.isaca.org/Knowledge-Center/cobit/Documents/COBIT4.pdf

[Accessed 2nd April 2017]. 
Jurevicius, O., 2014. IFE \& EFE Matrices. [Online] Available at: https://www.strategicmanagementinsight.com/tools/ife-efe-matrix.html[Accessed 3 April 2017].

Khusnir, K., Mlimulstein, Melina, L. \& Ramalho, R., 2010. Micro, Small and Medium Enterprise Around the World : How Many Are They and What the Effect of World Economy. Micro, Small and Medium Enterprise, The International Finance Corporation, World Bank Group, 3(1), pp. 1-8.

Rahman, H., 2006. SMEs In Indonesian Economy and Policies to Enhance Development and Empowerement of Indonesia. Haikou City, International Comparison on Private Sector Development Strategy.

Raz, A., 2012. The Euro Crisis and Its Impact on Indonesia's Economy. [Online] Available at: http://www.thejakartapost.com/news/2012/06/07/the-euro-crisis-andits-impact-indonesia-s-economy.html

Raz, A. F., 2012. The euro crisis and its impact on Indonesia's economy. [Online] Available at: http://www.thejakartapost.com/news/2012/06/07/the-euro-crisis-andits-impact-indonesia-s-economy.html [Accessed 26 February 2013].

Ritchie, J. \& Lewis, J., 2003. Qualitative Research Practice: A Guide for Social Science Students and Researchers. 1st ed. London: SAGE Publication.

Sarno, 2009. Audit Sistem \& Teknologi Informasi. 1st ed. Surabaya: ITS Press.

Scwhab, K. \& Brende, B., 2012. The Global Competitiveness Report 2012-2013, Geneva: World Economic Forum.

Tambunan, T., 2011. Trade Liberalization Effects on The Development of Small and Medium-Sized Enterprise in Indonesia. A Case Study of Asia-Pasific Development Journal, 13(2), pp. 35-59. 